\title{
Local Political Context and Polarization in the Electorate: Evidence from the 2004 Presidential Election
}

George Hawley

Political scientists have long examined the degree to which the American electorate exhibits partisan and ideological polarization and sought to explain the causal mechanism driving this phenomenon. Some scholars have argued that there is an increasing degree of geographic polarization of the electorate - that is, a large percentage of geographic units are becoming less politically heterogeneous. In this study, I argue that the two trends are related. Using individual-level data from the 2004 National Annenberg Election Survey, I examine the relationship between local partisan context and political attitudes using multilevel models. I find that, as the local political context becomes less competitive in national elections; those in the local political majority become more ideologically extreme, strengthen their partisan attachments, and hold more polarized attitudes toward the two major-party presidential candidates. These findings suggest that the growing geographic partisan segregation of the electorate is an important source of ideological and partisan polarization.

The polarization of the American electorate has long been a subject of intense debate among social scientists. The question of whether American political elites are more polarized now than in previous decades is now largely settled in the affirmative (Rhode 1991; Poole and Rosenthal 1997; McCarty et al. 2006). The presence of polarization in the electorate remains an unsettled question. While there is widespread agreement that the electorate has become more polarized in recent years (Abramowitz and Saunders 1998, 2002, 2008; Stonecash et al. 2003; Layman et al. 2006; Stoker and Jennings 2008), there is a cogent counterargument that polarization in the electorate is exaggerated (Fiorina et al. 2005).

Geographic polarization has also recently received scholarly attention in recent years (Abramowitz et al. 2006; Bishop 2008). That is, Americans are increasingly self-segregating into politically homogenous communities. In an increasing number of geographic units, candidates from one party can expect to consistently win overwhelming victories, and this geographic clustering of co-partisans is reducing the frequency of Americans' interactions with the politically dissimilar, though some scholars argue that this phenomenon is also exaggerated (Abrams and Fiorina 2012).

I argue that the two phenomena are related. That is, I contend that the local political context influences the probability that an individual will hold polarized political views. A large body of research suggests that polarization

GEORGE HAWLEY is an Honors College Teaching Fellow at the University of Houston.

The American Review of Politics, Vol. 34, Spring, 2013: 21-45

(C)2013 The American Review of Politics 
in the electorate is driven by changes among political elites-elites polarized, and the public subsequently polarized as a result (Zaller 1990; Hetherington 2001; Levendusky 2009). While I do not dispute this argument, I make the case that changes in American political geography also spurred changes in the degree to which the electorate is polarized. The results of my analysis demonstrate that the local political context exerts a meaningful influence on the probability that an individual will be a strong partisan, be highly ideological, and have highly polarized views of presidential candidates.

\section{Theory}

\section{Polarization in the Electorate}

Polarization is a perennial question in political science. Debates continue as to whether it is occurring in any meaningful way, as do discussions regarding the possible causal mechanisms driving it and its practical consequences. The polarization hypothesis in the United States has many variants, but its key idea is that there are two Americas and between these two camps there is a significant ideological divide.

James Hunter (1991) wrote an influential early text in this genre. Hunter argued that there was a substantial divide between those he deemed "progressive" and those he described as "orthodox." The former category of citizens believed that authority in a society was ultimately derived from human beings; the latter category tends to believe in a transcendent source of societal authority. This view of polarized American ideologies suggests that liberals and conservatives have fundamentally different, and irreconcilable, views about the world.

Some scholars have argued that the above categorization of ideological disputes does not provide an accurate picture of the American electorate (DiMaggio et al. 1996; Evans 1997, 2002, 2003). Perhaps the most famous recent salvo launched against the ideological polarization hypothesis was launched by Fiorina et al. (2005). They argued that there was not a deep or wide ideological chasm between different partisan groups in the electorate. The real ideological divide is found only among political elites. This view has a long history in political science; Converse (1964) argued that most voters actually have relatively few ideological constraints, and only a small fraction of any population develops a coherent and consistent ideology.

The debate continues, however, as many scholars continue to argue that polarization is a real phenomenon in the American electorate, and has important consequences (Stonecash et al. 2003; Layman et al. 2006; Stoker and Jennings 2008; Bafumi and Shapiro 2009; Dodsen 2010). The question of 
whether or not the American electorate is much more polarized now than it was in previous generations is beyond the scope of this article. Instead, I focus on the question of whether the local political context influences the probability that individuals will be on the extreme end of the partisan and ideological spectrum. By demonstrating that this is the case, a compelling argument can be made that the geographic partisan sort is a key cause of polarization in the electorate.

\section{The "Big Sort"}

American political scientists and political historians have always been aware of geographic differences in political attitudes and behavior. Increasingly, however, political scientists have turned their attention to an apparently recent trend in the United States: the geographic partisan sort. That is, some evidence suggests Republican and Democratic voters have been moving away from each other physically, and an increasing number of geographic units provide landslide victories to candidates belonging to one of the two major political parties. In the 1976 presidential election, just slightly over 26 percent of the American electorate lived in "landslide" countiesdefined by Bishop and Cushing in The Big Sort (2008) as counties in which one party won by 20 percentage points or more. By 2000 , the percentage of the electorate living in such counties reached 45.3 percent.

Other scholars have noted the recent rise in politically uncompetitive geographic units. Abramowitz, Alexander, and Gunning (2006) noted that, while both 1976 and 2004 were highly competitive elections, there were far fewer competitive states in the latter election. They also noted that the number of uncompetitive House seats has also increased and, what's more, redistricting is not the primary cause of the declining competitiveness of House elections. Gimpel and Shucknecht (2003) studied the increasing geographic divergence of the major parties, and demonstrated that migration is playing a key role in this trend. Chinni and Gimpel (2010) demonstrated via factor analysis that there are 12 "types" of counties in the U.S., each with unique political attributes, and several that overwhelmingly support one of the two major parties.

As with ideological and policy polarization, some scholars dispute the magnitude of the geographic partisan sort (Klinkner 2004). Gimpel et al. (2006) noted that there is little geographic variation between the two parties when it comes to campaign donations. Abrams and Fiorina (2012) made the case that there has not been a substantive increase in geographic partisan clustering at all, suggesting that Bishop's use of presidential vote choice at the county level was an improper measure, and further argued that its effects would not be very important, even if it occurred. Addressing the magnitude 
of the geographic partisan sort in the United States is beyond the scope of this paper. However, I disagree with the claim that the partisan makeup of a community has little influence on political attitudes and behavior. In the pages ahead I will make the case that the partisan context of counties does influence the attitudes of Americans, particularly Americans who identify with a particular party.

\section{Local Context and Political Attitudes}

Political scientists have long believed that local political context can influence individual attitudes (Books and Prysby 1988). Berelson et al. (1954) argued that the stability of political preferences is a function of how much social support individuals have for those preferences. Thus, as the local community becomes increasingly supportive of one political viewpoint in the aggregate, individuals who may otherwise have held dissenting opinions should increasingly conform their views to the views of the majority, and those already sharing the majority opinion may become even more ideologically calcified. As a result of this sorting process, we may see an increasing number of people supporting a political party at odds with their personal interests or holding views more extreme than would necessarily be predicted based on their individual attributes.

Berelson et al.'s (1954) findings have been reexamined since the initial publication of their work. MacKuen and Brown (1987) also found that local context shapes individual views; they demonstrated that individual attitudes toward parties and politicians were heavily influenced by their neighbors' attitudes - though they did not find that partisan affiliation was similarly sensitive.

Local context also plays an important role in the development of individual communication networks. Putnam (1966) found that the partisanship of friendship groups was largely related to the aggregate community partisanship distribution. Huckfeldt (1983) also found that our friendship networks are heavily determined by the local context, a finding confirmed by other scholars (Mollenhorts et al. 2008). We should not overstate this, however. For most people, the desire to create a social network of likeminded people is quite strong (McPherson et al. 2001) Even when a community is overwhelmingly Republican or Democratic, individuals who are political minorities at the local level will nonetheless often be able to seek out and befriend those who are likeminded politically. Finifter (1974) studied friendship groups among predominantly Democratic Detroit autoworkers. He found that Republican autoworkers tended to congregate together and thus created a protective social group for themselves. In spite of this caveat, however, it is clear that Democrats (Republicans) in predominantly Republican 
(Democratic) communities will have more Republicans (Democrats) in their social networks than would be the case in a different social context.

The relationship between community/neighborhood context and communication networks is important because the people we interact with influence our political attitudes. Huckfeldt et al. (2004) found that politically heterogeneous social networks tend to increase ambivalence toward politics. That is, those with a social network that contain a wide variety of political attitudes should become more conflicted in their own attitudes. Therefore, we may expect political minorities in uncompetitive counties to be highly ambivalent about politics and be more likely to withdraw from political participation (Mutz 2002a; McClurg 2006). In contrast, those in the majority in landslide communities should presumably have highly homogenous discussion networks and be less ambivalent in their political attitudes.

We might expect that those with less politically diverse discussion networks to be less tolerant of those with opposing political views. As the contact hypothesis (Allport 1954) suggests, those who never interact with those who belong to a different political party may subscribe to the crudest stereotypes about such people, and exhibit much more hostility to opposing partisans than those who interact with a politically diverse network. Mutz (2002b) demonstrated that politically diverse networks were associated with greater tolerance and support for civil liberties.

Based on these findings, we can expect that, even when controlling for other individual and contextual variables, the local political context should influence the strength of partisan and ideological inclinations. More specifically, I hypothesize that as the local political context becomes more Republican (Democratic), Republicans (Democrats) will become more likely to identify as very conservative (liberal), to express a strong ideological attachment, and hold a much higher opinion of the presidential candidate belonging to their party than the opposing candidate. I argue that this is the case because residents in the political majority living in uncompetitive counties will encounter fewer people with whom they disagree and hear fewer dissenting opinions. As a result, they are less ambivalent about their political party and ideology.

\section{Data and Methods}

The 2004 National Annenberg Election Survey (NAES) provided the individual-level survey responses used to test my hypotheses. ${ }^{1}$ These data benefit from a large $n$ (more than 90,000 respondents), and provide the county of residence for each respondent. The latter characteristic is particularly important because I specifically hypothesize that the local political context plays an important role in shaping political and ideological views. 
The decision to use the county level for contextual variables deserves some explanation. To a certain extent, the use of counties may substantially underestimate the trend toward geographic sorting. Even if a county, in the aggregate, is politically heterogeneous, it may actually be remarkably segregated, politically or otherwise. In the South, for example, there are a substantial number of counties containing communities that are overwhelmingly black or white. Although these counties may appear evenly divided politically, the disproportionately Republican whites and the overwhelmingly Democratic African Americans may actually rarely interact and live in geographically separate neighborhoods. Even in demographically homogenous counties, the appearance of political heterogeneity may be masking underlying segregation. In Whatcom County, Washington, which is 88 percent non-Hispanic white, the voters in the large city of Bellingham, home of Western Washington University, overwhelmingly support Democratic candidates; however, the agricultural communities in that county vote disproportionately for Republicans. The average resident of Whatcom County will therefore likely live her life just as politically segregated as a resident in any landslide county, though the county appears, in the aggregate, to be relatively competitive.

Why, then, the emphasis on counties? First, it should be obvious that larger geographic units, such as regions, states, metropolitan statistical areas, and congressional districts are simply much too large to be usefully used for this kind of analysis. There are smaller geographic units one could potentially use for this kind of research, such as census tracts. However, the most useful data one can readily access for census tracts are those provided by the Census Bureau itself - other contextual variables of interest, such as the forms of religious participation prevalent in a community, are only available at the county level. Counties are therefore the smallest geographic unit for which a large amount of reliable data can be gathered from multiple sources and used to usefully explore this issue. If further justification for my emphasis on counties as the primary unit of analysis is needed, I can only point out that other scholars examining questions relating to local context and political attitudes have successfully used counties for several decades (Miller 1956; Putnam 1966; Brown 1988; McVeigh and Sobolewski 2007; Chinni and Gimpel 2010). Counties are also the unit of analysis used by Bishop (2008), who is largely responsible for the current debates about geographic sorting.

Because counties are a relatively large unit of analysis in comparison to neighborhoods or census tracts, they constitute a difficult test for my hypotheses. That is, if results at the county level are consistent with my expectations, it is likely that even stronger results would be found if smaller geographic units of analysis were employed. 
Because I am considering both individual- and contextual-level variables, multilevel models are the proper method for performing these analyses. Specifically, in all cases I created three-level random-intercept models in which individuals were nested in counties which were nested in states (Steenbergen and Jones 2002).

A large number of individual-level variables are highly correlated with party identification and the strength of ideological attachments. Aggregate level support in a community for one political party versus another is also highly correlated with other community characteristics. For these reasons, a large number of individual and contextual independent variables were necessary in order ensure that it is specifically the local political context that is influencing attitudes.

Among individuals, ideology and party identification, and the strength of that identification, are predicted by a number of individual attributes. Evidence of ideological and partisan polarization is particularly strong among the well educated (Hetherington 2001), thus a dummy variable measuring whether or not a respondent had completed a four-year college degree was included in all models. Married voters are more likely to be strong Republicans (Gershkoff 2009) than are the unmarried, thus marital status was included. One of the strongest predictors of Republican identification is the strength of religious commitment (Hunter 1991), thus a dummy variable for religiosity was included in all models that distinguishes those who attend religious services once a week or more from those who attend less than that or never. Because of the strong relationship between income and vote choice (Gelman et al. 2008; Brewer and Stonecash 2007), dummy variables for income quartile were included in all models, with those in the lowest category serving as the base category. Because younger voters tend to have weaker partisan and ideological commitments (Jennings and Markus 1984), dummy variables for age categories were also included, with the youngest respondents serving as the excluded base category. Finally, dummy variables for race and ethnicity were included, given the strong support the Democratic Party has traditionally received from minorities, particularly African Americans (Walton and Smith 2006; McClerking 2009). All of these individual attributes were provided in the Annenberg data.

Because I hypothesized that the local political context was a key predictor of strong party identification and ideological extremity, the percent of a respondent's county that voted for George W. Bush in 2004 was the key independent variable in all models. It was also important to control for a large number of local community attributes that also predict the aggregate vote choice within a community. The racial and ethnic composition of the county was included in all models. Dummy variables for whether the local community was predominantly rural, suburban, or urban included, with rural 
excluded from all models, as was a continuous variable for the county-level unemployment rate in 2004. Finally, because counties containing large numbers of Evangelical Christians are also some of the most consistentlyRepublican counties (Chinni and Gimpel 2010), the percentage of each county that belonged to an Evangelical congregation was also included; unlike the other contextual variables in these models, this final variable is not collected by any government agency. However, the Glenmary Research Center (Jones et al. 2002) conducted a national survey of religious congregations in 2000 that was used to estimate the percentage of each county in the U.S. that belonged to different denominations. These data were used to estimate the percentage of each county that belonged to an Evangelical church. Because of its unique political history and attributes (Key 1949; Woodard 2006), a state-level dummy variable for Southern vs. non-Southern states was included, as well.

In all of the tables presented in the forthcoming section, separate regression models were performed for Republicans and Democrats. Independents who expressed no partisan preference whatsoever were excluded. Independents who nonetheless admitted that they "leaned" toward one party or the other were classified as being members of that party. This decision was made because self-described independents who nonetheless admit to leaning toward a particular party are often just as partisan as those who immediately identify with a particular party (Keith et al. 1992).

\section{Results}

\section{Local Context and the Probability of Being a "Strong" Partisan}

By definition, an electorate exhibiting signs of high partisan polarization is one in which voters are strongly attached to their parties. In contrast, we would expect an electorate that is not polarized along partisan lines to be dominated by voters with weak party attachments who are willing to vote for different parties depending on the circumstances or the candidate. As is common in political public opinion polls, the Annenberg survey asked respondents party identification, and followed up this question by asking whether that party attachment was "strong."

A large percentage of NAES respondents who claimed to belong to a particular party also said their commitment to that party was "strong." Among Republicans, 58.5 percent said that they were "strong Republicans"; among Democrats, that number was 56.7. Thus, it was quite common for partisans to express strong attachments to their parties in 2004-not an unexpected finding given the research suggesting a more polarized electorate. The more interesting question, for the purposes of this paper, is whether 
there is a relationship between the local aggregate political context and the probability that an individual will possess a strong partisan affiliation.

Figure 1 was created by summarizing the percent of each county's partisans who expressed a "strong" party attachment. These county percentages for both partisan groups were then plotted as a function of the local distribution of votes in the 2004 presidential election. This figure was generated using only those counties in which there were 20 or more NAES respondents. Because a large number of counties, particularly rural or lightly populated counties, had only one respondent, including them would have strongly overestimated the percentage of counties in which 100 percent of respondents claimed to be strong partisans or not strong partisans. Fitted lines were then estimated for the percentage of Republicans and Democrats in a county who expressed strong partisan attachments as a function of the aggregate county political context.

Figure 1 shows an apparent relationship between the county political context and the probability that a large percentage of a county's NAES partisan respondents claimed to have strong partisan attachments. As support for Bush increased, the percentage of Republican respondents in a county who expressed a strong commitment to their party also increased; the reverse was true for Democrats. The results were not strong, however, and in all contexts, the predicted county percent was greater than 50 percent.

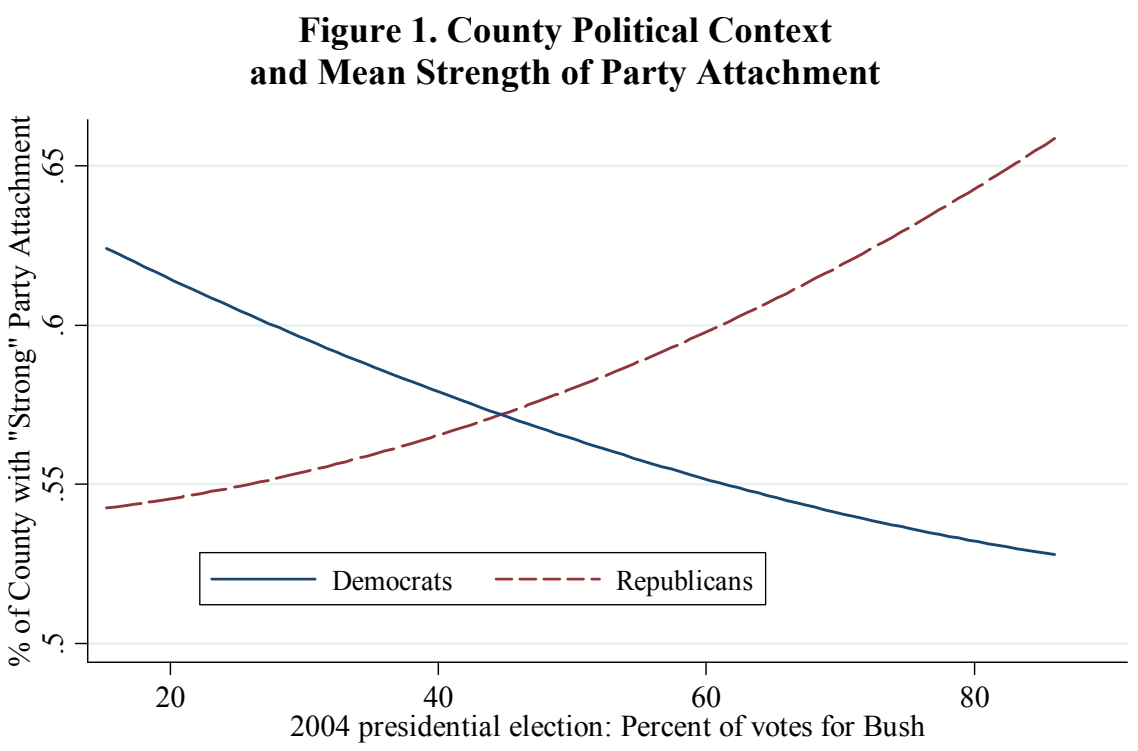


It is possible that these findings are spurious. As noted previously, a county's aggregate political characteristics correspond with many other variables, which may actually be responsible for the perceived difference in county means. To determine whether the local partisan context had a statistically discernable influence on individual probabilities of being strong partisans, I generated a three-level multilevel logit model, in which those who claim to be "strong" partisans are coded as 1 , and other responses are coded as 0 , the results of which can be found in Table 1 .

Table 1 provides a number of interesting results. First of all, it demonstrates that Republicans and Democrats differ systematically when it comes to what predicts the strength of their partisan affiliations. For Republicans, being married, attending a religious service once a week or more, and having a higher annual income were associated with a greater probability of proclaiming a strong partisan attachment; none of these individual-level variables were statistically significant for Democrats. Among Democrats, possessing a four-year degree, being a woman, and being an African American were associated with a greater probability of being a strong partisan; similarly, none of these variables had a statistically discernable influence on Republicans. Among both partisan groups, a higher age was associated with a higher probability of possessing a strong party identification.

Turning to the contextual variables, we see that, in comparison to residents in rural counties, residents in urban counties were more likely to be strong partisans, and this was true for both Republicans and Democrats. Interestingly, we also see that Democrats living in the South were more likely to say they were "strong" Democrats than Democrats elsewhere, but the same was not true of Republicans. It is worth noting, however, that this was only weakly significant and that this was not the case in 2008 (see Appendix).

Turning to our main variable of interest, local political context, we see that the results are consistent with expectations. As the percentage of a county's vote for Bush increased, Republicans became more likely to say they were "strong Republicans," but Democrats became less likely to claim to be "strong Democrats." In both models, this variable was highly statistically significant. Although its substantive significance was modest in comparison to some individual-level variables such as age, these results suggest that, if the electorate becomes more politically segregated geographically, the number of strong party identifiers will also increase.

\section{Local Context and the Probability of Being "Very Conservative" or "Very Liberal"}

Perhaps partisan attachment is a less interesting measure of polarization than ideology. Presumably the voters most responsible for polarizing the 


\section{Table 1. Multilevel Logit Model for Probability Respondents Were "Strong" Partisans}

\begin{tabular}{|c|c|c|c|c|c|c|c|c|}
\hline & $\begin{array}{c}\text { Model 1 } \\
\text { Republicans }\end{array}$ & S.E. & $\begin{array}{l}\text { Odds } \\
\text { Ratio }\end{array}$ & S.E. & $\begin{array}{c}\text { Model } 2 \\
\text { Democrats }\end{array}$ & S.E. & $\begin{array}{l}\text { Odds } \\
\text { Odds }\end{array}$ & S.E. \\
\hline \multicolumn{9}{|l|}{ FIXED EFFECTS } \\
\hline \multicolumn{9}{|l|}{ Individual } \\
\hline Constant & -0.64 & $(0.11)^{* *}$ & & & -0.14 & $(0.10)$ & & \\
\hline Married & 0.12 & $(0.03)^{* *}$ & 1.13 & $(0.03)$ & -0.02 & $(0.02)$ & 0.98 & $(0.02)$ \\
\hline BA & -0.03 & $(0.02)$ & 0.97 & $(0.02)$ & 0.21 & $(0.02)^{* *}$ & 1.24 & $(0.03)$ \\
\hline Female & -0.03 & $(0.02)$ & 0.97 & $(0.02)$ & 0.05 & $(0.02)^{*}$ & 1.05 & $(0.02)$ \\
\hline Black & 0.12 & $(0.09)$ & 1.13 & $(0.10)$ & 0.65 & $(0.04)^{* *}$ & 1.91 & $(0.07)$ \\
\hline Hispanic & -0.23 & $(0.05)^{* *}$ & 0.80 & $(0.04)$ & -0.06 & $(0.04)$ & 0.94 & $(0.04)$ \\
\hline \multicolumn{9}{|l|}{ Frequently Attend } \\
\hline Religious Services & 0.40 & $(0.02)^{* *}$ & 1.49 & $(0.03)$ & 0.00 & $(0.02)$ & 1.00 & $(0.02)$ \\
\hline Age $30-44$ & 0.14 & $(0.04)^{* *}$ & 1.15 & $(0.04)$ & 0.18 & $(0.03)^{* *}$ & 1.20 & $(0.04)$ \\
\hline Age $45-60$ & 0.34 & $(0.04)^{* *}$ & 1.41 & $(0.05)$ & 0.57 & $(0.03)^{* *}$ & 1.76 & $(0.06)$ \\
\hline Age $61+$ & 0.57 & $(0.04)^{* *}$ & 1.77 & $(0.07)$ & 0.92 & $(0.04)^{* *}$ & 2.50 & $(0.09)$ \\
\hline Income Quartile 2 & 0.05 & $(0.04)$ & 1.05 & $(0.04)$ & -0.01 & $(0.03)$ & 0.99 & $(0.03)$ \\
\hline Income Quartile 3 & 0.15 & $(0.04)^{* *}$ & 1.16 & $(0.04)$ & -0.03 & $(0.03)$ & 0.97 & $(0.03)$ \\
\hline Income Quartile 4 & 0.28 & $(0.05)^{* *}$ & 1.33 & $(0.06)$ & 0.05 & $(0.04)$ & 1.06 & $(0.05)$ \\
\hline Income Unknown & 0.08 & $(0.05)$ & 1.09 & $(0.05)$ & -0.04 & $(0.04)$ & 0.96 & $(0.04)$ \\
\hline \multicolumn{9}{|l|}{ Community } \\
\hline$\%$ Bush 2004 & 0.01 & $(0.00)$ & 1.01 & $(0.00)$ & -0.01 & $(0.00)^{* *}$ & 0.99 & $(0.00)$ \\
\hline$\%$ Black & 0.00 & $(0.00)$ & 1.00 & $(0.00)$ & 0.00 & $(0.00)$ & 1.00 & $(0.00)$ \\
\hline$\%$ Hispanic & 0.00 & $(0.00)$ & 1.00 & $(0.00)$ & 0.00 & $(0.00)$ & 1.00 & $(0.00)$ \\
\hline Urban & 0.10 & $(0.04)$ & 1.11 & $(0.04)$ & 0.13 & $(0.04)^{* *}$ & 1.14 & $(0.04)$ \\
\hline Suburban & 0.02 & $(0.03)$ & 1.02 & $(0.03)$ & 0.04 & $(0.03)$ & 1.04 & $(0.03)$ \\
\hline Unempl. Rate, 2004 & 0.00 & $(0.01)$ & 1.00 & $(0.01)$ & 0.02 & $(0.01)$ & 1.02 & $(0.01)$ \\
\hline$\%$ Evang. Christian & 0.00 & $(0.00)$ & 1.00 & $(0.00)$ & 0.00 & $(0.00)$ & 1.00 & $(0.00)$ \\
\hline \multicolumn{9}{|l|}{ State } \\
\hline South & 0.06 & $(0.05)$ & 1.06 & $(0.05)$ & 0.12 & $(0.05)^{*}$ & 1.13 & $(0.05)$ \\
\hline \multicolumn{9}{|l|}{ RANDOM EFFECTS } \\
\hline \multicolumn{9}{|l|}{ County-Level } \\
\hline $\begin{array}{l}\text { Constant } \\
\sqrt{\psi}_{\psi}\end{array}$ & & \\
\hline \multicolumn{9}{|l|}{ State-Level } \\
\hline \multicolumn{8}{|l|}{ Constant } & \\
\hline \multicolumn{9}{|l|}{ GROUPS } \\
\hline \multicolumn{8}{|l|}{ Level-1 Observations } & \\
\hline \multicolumn{2}{|l|}{$\begin{array}{l}\text { (Individual) } \\
\text { Level-2 Observations }\end{array}$} & & & & & & & \\
\hline \multicolumn{2}{|l|}{$\begin{array}{l}\text { Level-2 Observations } \\
\text { (County) }\end{array}$} & 2647 & & & & 71 & & \\
\hline \multicolumn{9}{|l|}{ Level-3 Observations } \\
\hline-2 X Log Likelihood & & $\begin{array}{c}48 \\
45835.28\end{array}$ & & & 48 & 45.064 & & \\
\hline
\end{tabular}


American electorate are those who claim to be "very liberal" and "very conservative." It may be that strong ideologues tend to live in politically homogenous counties. If those residing in politically uncompetitive communities have fewer interactions with those whom they disagree politically, individuals living in such a context who share the majority viewpoint should be less ambivalent and more convinced that their views are correct; in contrast, those living in a more heterogeneous community should presumably encounter competing, and compelling, arguments from multiple sides, and as a result be more willing to consider competing ideas and more likely to hold moderate political positions.

The percentage of the electorate that describes themselves as "very liberal" or "very conservative" is quite small. Among Democratic respondents to the NAES survey, only 8.69 percent labeled themselves as "very liberal." Among Republicans, the number calling themselves "very conservative" was a higher, but still small, 14.09 percent. The percentage of very conservative Republicans and very liberal Democrats may not be evenly distributed throughout the nation, however. Figure 2 was generated using the same method used to generate Figure 1. It shows the percentage of Republicans in each county who describe themselves as "very conservative," and Democrats who call themselves "very liberal," as a function of the local partisan context - again, only those counties with more than 20 observations were used to generate this figure.

\section{Figure 2. County Political Context and Mean Strength of Ideology}

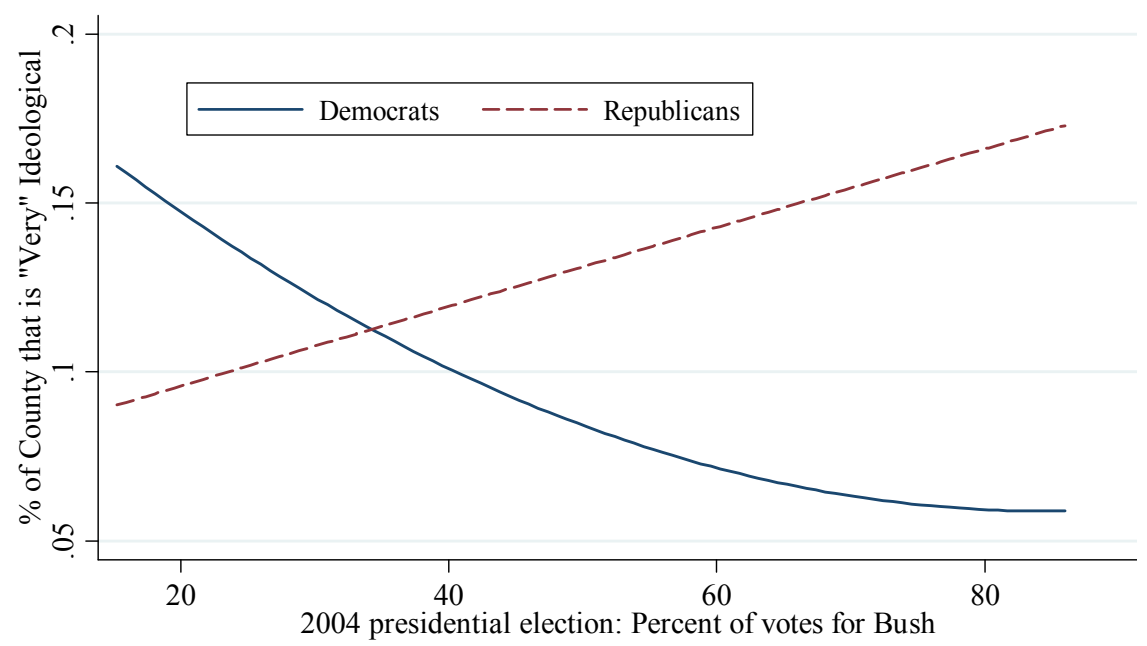


In Figure 2 we see a pattern analogous to that of Figure 1. In the overwhelmingly Democratic counties, a comparatively large percentage of Democratic respondents described themselves as "very liberal." Similarly, in the landslide Republican counties, a relatively large percentage of Republicans identified as "very conservative." It must be noted, however, that the difference between strong Republican, competitive, and strong Democratic counties in regard to the likelihood that a large number of respondents identified as a strong ideologue was relatively modest, and in all cases, only a small percentage of respondents so identified.

Again, to ensure that any relationship between local political context and the probability of being an extreme ideologue is not spurious, a more sophisticated statistical analysis is necessary. As before, I analyzed this relationship using a three-level multilevel logit model that examined Republican and Democratic respondents separately. For Republican respondents, those who claimed to be "very conservative" were classified as 1, and all other were classified as 0 ; for Democrats, those who called themselves "very liberal" were categorized as 1 , and others were categorized as 0 . The results of these models can be found in Table 2.

Again, we see considerable variation between Republicans and Democrats. Married, older, and religiously observant Republicans were, on average, more likely to describe themselves as "very conservative." Hispanic, female, four-year degree holders, and, interestingly, wealthy Republicans were less likely to describe themselves as such. Among Democrats, marriage, religiosity, being African American or Hispanic, being older, and having any income higher than the lowest quartile were all associated, on average, with a lower probability of being "very liberal." Gender and educational attainment were the only variables that influenced the probability that a Democrat would be on the far left side of the ideological spectrumDemocratic women and the well educated were both more likely to be very liberal.

Turning to the contextual variables, we see considerable differences between Republicans and Democrats; we further see that different contextual variables influenced the strength of ideology than influenced the strength of partisanship. The unemployment rate was the only variable that was statistically discernable in Models 3 and 4. For Republicans, a higher local unemployment rate increased, on average and controlling for all other variables, the probability of being "very conservative"; for Democrats, greater local unemployment was associated with a lower probability of being "very liberal."

In contrast to the strength of partisanship, the local political context had no statistically significant influence on the probability that a Republican would be on the far-right end of the ideological spectrum. However, the 
Table 2. Multilevel Logit Model for Probability Republican Respondents Described Themselves as "Very Conservative" and Democratic Respondents Described Themselves as "Very Liberal"

\begin{tabular}{|c|c|c|c|c|c|c|c|c|}
\hline & $\begin{array}{c}\text { Model 3 } \\
\text { Republicans }\end{array}$ & S.E. & $\begin{array}{l}\text { Odds } \\
\text { Ratio }\end{array}$ & S.E. & $\begin{array}{c}\text { Model } 4 \\
\text { Democrats }\end{array}$ & S.E. & $\begin{array}{l}\text { Odds } \\
\text { Odds }\end{array}$ & S.E. \\
\hline \multicolumn{9}{|l|}{ FIXED EFFECTS } \\
\hline Constant & -3.01 & $(0.16)^{* *}$ & & & -0.62 & $(0.19)^{* *}$ & & \\
\hline Married & 0.23 & $(0.04)^{* *}$ & 1.26 & $(0.05)$ & -0.37 & $(0.04)^{* *}$ & 0.69 & $(0.03)$ \\
\hline BA & -0.12 & $(0.04)^{* *}$ & 0.89 & $(0.03)$ & 0.69 & $(0.04)^{* *}$ & 1.98 & $(0.08)$ \\
\hline Female & -0.16 & $(0.03)^{* *}$ & 0.85 & $(0.03)$ & 0.10 & $(0.04)^{*}$ & 1.10 & $(0.04)$ \\
\hline Black & 0.14 & $(0.12)$ & 1.15 & $(0.14)$ & -0.32 & $(0.07)^{* *}$ & 0.73 & $(0.05)$ \\
\hline Hispanic & -0.38 & $(0.09)^{* *}$ & 0.68 & $(0.06)$ & -0.29 & $(0.08) * *$ & 0.75 & $(0.06)$ \\
\hline \multicolumn{9}{|l|}{ Frequently Attend } \\
\hline Religious Services & 1.00 & $(0.03)^{* *}$ & 2.72 & $(0.09)$ & -0.60 & $(0.05)^{* *}$ & 0.55 & $(0.03)$ \\
\hline Age $30-44$ & 0.16 & $(0.05)^{* *}$ & 1.17 & $(0.06)$ & -0.30 & $(0.05)^{* *}$ & 0.74 & $(0.04)$ \\
\hline Age $45-60$ & 0.14 & $(0.05)^{*}$ & 1.15 & $(0.06)$ & -0.36 & $(0.05)^{* *}$ & 0.70 & $(0.04)$ \\
\hline Age $61+$ & 0.09 & $(0.06)$ & 1.09 & $(0.06)$ & -0.53 & $(0.06)^{* *}$ & 0.59 & $(0.04)$ \\
\hline Income Quartile 2 & 0.05 & $(0.05)$ & 1.05 & $(0.06)$ & -0.16 & $(0.06)^{* *}$ & 0.85 & $(0.05)$ \\
\hline Income Quartile 3 & -0.01 & $(0.06)$ & 0.99 & $(0.06)$ & -0.24 & $(0.06)^{* *}$ & 0.79 & $(0.05)$ \\
\hline Income Quartile 4 & -0.16 & $(0.07) * *$ & 0.85 & $(0.06)$ & -0.22 & $(0.07)^{* *}$ & 0.80 & $(0.06)$ \\
\hline Income Unknown & 0.12 & $(0.07)$ & 1.13 & $(0.07)$ & -0.30 & $(0.08)^{* *}$ & 0.74 & $(0.06)$ \\
\hline \multicolumn{9}{|l|}{ Community } \\
\hline \% Bush 2004 & 0.00 & $(0.00)$ & 1.00 & $(0.00)$ & -0.02 & $(0.00)^{* *}$ & 0.98 & $(0.00)$ \\
\hline$\%$ Black & 0.00 & $(0.00)$ & 1.00 & $(0.00)$ & 0.00 & $(0.00)$ & 1.00 & $(0.00)$ \\
\hline$\%$ Hispanic & 0.00 & $(0.00)$ & 1.00 & $(0.00)$ & 0.00 & $(0.00)$ & 1.00 & $(0.00)$ \\
\hline Urban & -0.02 & $(0.05)$ & 0.98 & $(0.05)$ & 0.05 & $(0.07)$ & 1.05 & $(0.07)$ \\
\hline Suburban & -0.01 & $(0.04)$ & 0.99 & $(0.04)$ & -0.12 & $(0.06)$ & 0.88 & $(0.06)$ \\
\hline Unempl. Rate, 2004 & 0.03 & $(0.01)^{*}$ & 1.03 & $(0.01)$ & -0.08 & $(0.02)^{* *}$ & 0.93 & $(0.02)$ \\
\hline$\%$ Evang. Christian & 0.01 & $(0.00)^{* *}$ & 1.01 & $(0.00)$ & 0.00 & $(0.00)$ & 1.00 & $(0.00)$ \\
\hline \multicolumn{9}{|l|}{ State } \\
\hline South & 0.07 & $(0.08)$ & 1.07 & $(0.08)$ & 0.01 & $(0.05)$ & 1.01 & $(0.10)$ \\
\hline \multicolumn{9}{|l|}{ RANDOM EFFECTS } \\
\hline \multicolumn{9}{|l|}{ County-Level } \\
\hline $\begin{array}{l}\text { Constant } \\
\sqrt{\psi}_{\psi}\end{array}$ & 0.03 & $(0.17)$ & & & 0.17 & $(0.05)$ & & \\
\hline \multicolumn{9}{|l|}{ State-Level } \\
\hline $\begin{array}{l}\text { Constant } \\
\sqrt{ }_{\psi}\end{array}$ & 0.15 & $(0.03)$ & & & 0.14 & $(0.03)$ & & \\
\hline \multicolumn{9}{|l|}{ GROUPS } \\
\hline \multicolumn{8}{|l|}{ Level-1 Observations } & \\
\hline \multicolumn{2}{|l|}{$\begin{array}{l}\text { (Individual) } \\
\text { Level-2 Observations }\end{array}$} & 2647 & & & & 571 & & \\
\hline \multicolumn{5}{|l|}{ Level-3 Observations } & & \multicolumn{3}{|l|}{46} \\
\hline \multicolumn{2}{|l|}{$\begin{array}{l}\text { (State) } \\
-2 \text { X Log Likelihood }\end{array}$} & 26997.87 & & & 205 & 563.794 & & \\
\hline
\end{tabular}


local religious context did have such an influence; as the percentage of Evangelical Christians in a Republican's county increased, the probability of that Republican identifying as a "very conservative" also increased. For Democrats, the local political context did influence the probability of being "very liberal," and the affect was in the expected direction.

\section{Local Context and Polarized Attitudes toward Political Figures}

We might also think of a polarized electorate as one in which individuals hold polarized views regarding politicians. That is, in a less polarized context, we may expect most voters to only weakly prefer one candidate to the other. In contrast, in a highly polarized context we could expect most voters to be highly enthusiastic about their preferred candidate, and despise that candidate's opponent. The 2004 NAES survey asked respondents to provide a favorability rating for both John Kerry and George W. Bush. The scale went from 0 to 10 , with 0 representing a very low favorability, and 10 representing a very high favorability.

Using these two questions, I constructed a new variable representing the gap between the two scores. That is, a variable that tells us whether the respondent held polarized attitudes toward the two respondents. A score of 10 on this variable would indicate that the respondent gave one candidate the highest possible rating and the opposing candidate the lowest possible rating, and a score of 0 indicates that the respondent gave both candidates the exact same score - that is, exhibited no evidence of a polarized attitude toward the two candidates.

Among all NAES respondents, the mean score for this difference-inapproval variable was 5.06, with a standard deviation of 3.15. Republicans, on average, scored slightly higher than Democrats on this score, 5.48 versus 5.01. Again, a figure was useful for making an initial determination of whether there are systematic differences in this variable based on different county contexts. Figure 3 shows how the mean county polarization score for Republicans and Democrats changed based on the aggregate county political outcome of the 2004 presidential election. In this case, it appears that Republicans were more sensitive to the local context than were Democrats.

A three-level multilevel model was again created to further explore this possible relationship. Because the dependent variable in this case was continuous, rather than dichotomous, a linear model was employed. The results of the model can be found in Table 3 .

The results of Table 3 are congruent with expectations. As the percentage of the local vote that went Republican increased in the 2004 election, the approval gap between Bush and Kerry increased among Republicans, but decreased among Democrats. That is, Republicans who lived primarily 


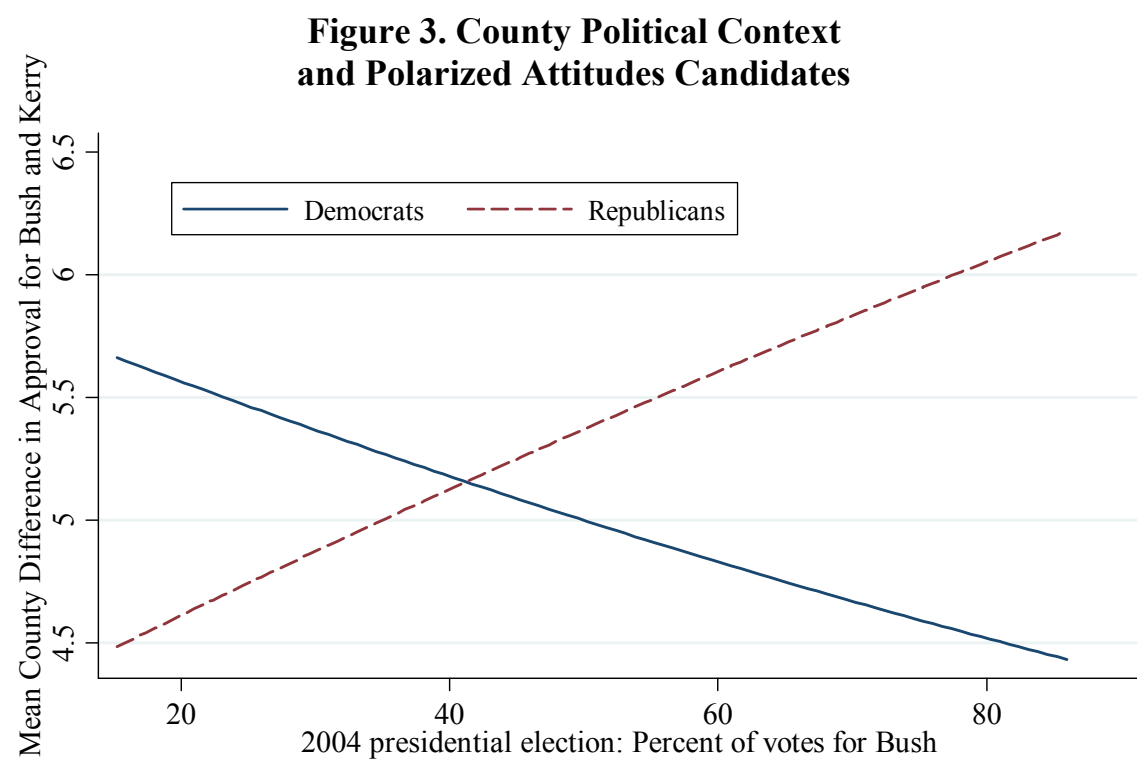

among other Republicans tended to like Bush much more than Kerry, and Democrats living in overwhelmingly Democratic communities had a much higher opinion of Kerry than of Bush; in evenly split communities, the gap was smaller for both partisan groups. As was the case with Table 2, we see also that a larger percentage of a county belonging to an Evangelical Christian congregation, on average and controlling for all other variables, increased the approval gap for Republicans, as did a larger local black population and a larger county unemployment rate. Among Democrats, larger county African American and Hispanic populations were both associated with a lower approval gap. It is useful to note, that, when looking at substantive significance, the local political context was much more influential than any other contextual variable for both partisan groups.

\section{Conclusion}

Based on these results, we can be reasonably concerned that residential political balkanization is leading to a more extreme, polarized electorate. Although this does not address the critique that the geographic partisan sort has been exaggerated (Klinkner 2004: Abrams and Fiorina 2012), it does suggest that the political context of counties does influence the political attitudes of partisans. In politically uncompetitive counties, partisans are more likely to have strong partisan affiliations, be on the extreme end of the 


\section{Table 3. Multilevel Linear Model for Difference in Bush-Kerry Favorability Scores}

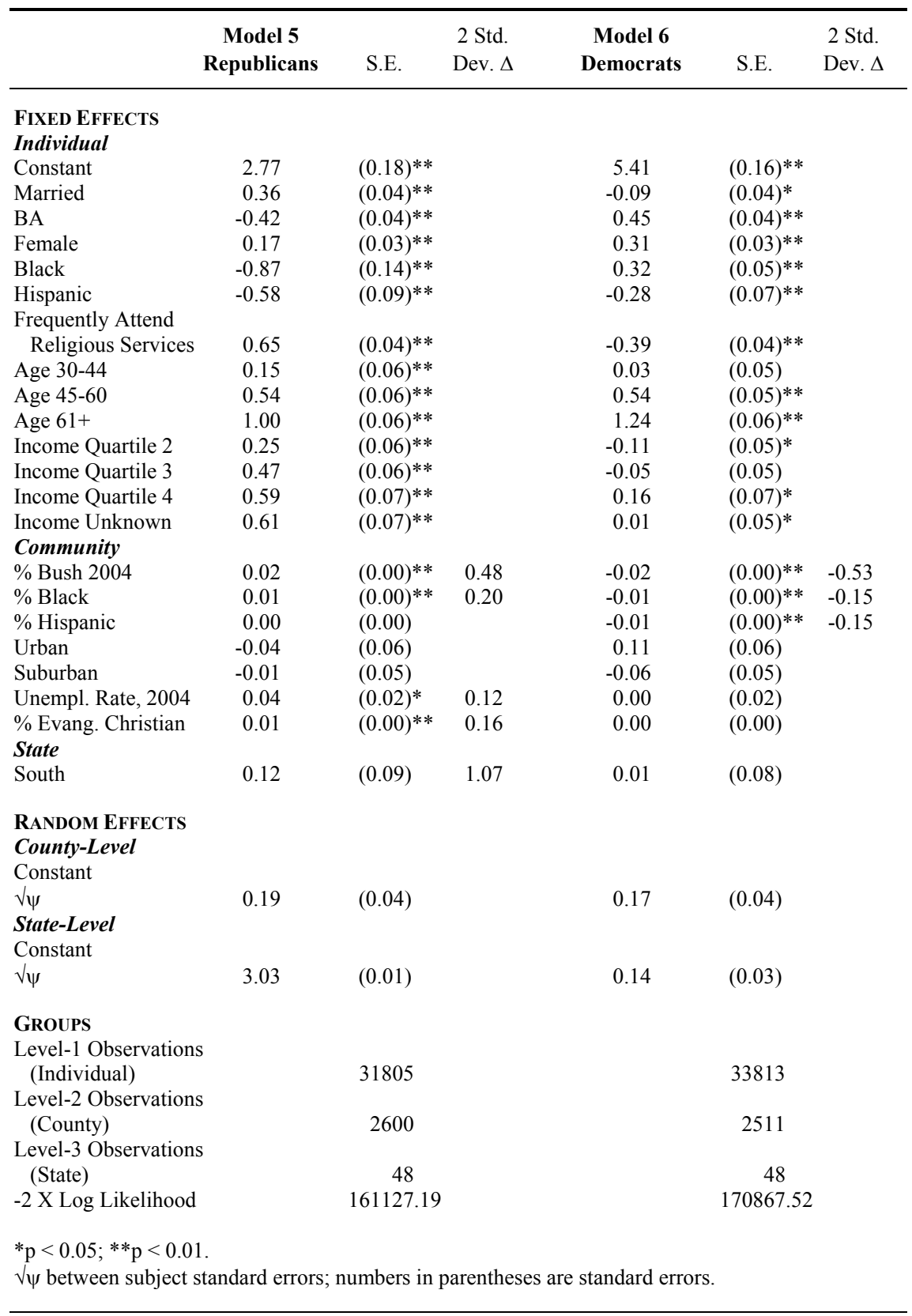


ideological spectrum, and hold highly polarized views toward competing presidential candidates. What's more, these effects were consistent and highly significant despite the potential problems caused by the use of relatively large second-level units (counties). If we explored smaller geographic entities, such as neighborhoods or census tracts, the results would likely have been even stronger.

If a moderate, less extreme electorate is our normative goal, then a growth of politically uncompetitive geographic units is a problematic trend. Scholars are therefore right to be interested in the percentage of Americans living in "landslide" counties (Bishop 2008). As the number of Americans without neighbors who can provide competing political arguments increases, the number of ideologically rigid and inflexible partisans should rise as well.

That being said, a few caveats are necessary. Although the findings presented here were consistent with my hypotheses, and the key independent variable achieved a high level of statistical significance in most cases even with the large number of independent variables included in all models, the substantive significance was not large in most cases. Given the modest findings presented here, it is unlikely that residential patterns are the sole cause of rising polarization in the electorate- though it should be noted that the growth of polarized attitudes may itself be relatively modest (Fiorina et al. 2005; Fischer and Mattson 2009).

It is also possible that, although the findings presented here were congruent with my theory, a fundamentally different causal process was at work. I hypothesized that living in a politically competitive community led to lower levels of polarization because personal interactions with the politically dissimilar created higher levels of political tolerance and ambivalence. It could be that residents in such communities are actually being influenced by some other phenomenon. Perhaps residents of competitive counties are more likely to encounter advertisements, mailings, and door-to-door political advocates from all sides of the political divide, and this is what causes their lower probability of being strong partisans and intense ideologues.

It is also possible that self-selection in migration is the primary cause of this finding. It is possible that strong partisans and committed ideologues are intentionally moving to live among the politically likeminded. If that is the case, then the geographic partisan sort is not changing the number of strong partisans in the electorate, only influencing where they live. Brown's (1988) findings on migration and politics suggest that it is highly unlikely that this occurs frequently enough to account for the findings here, but trends in American migration patterns may have changed since the 1980s, and his work needs to be updated.

There are other possible measures of polarization beyond those employed in this study. For example, it would be useful to determine whether 
there is a higher or lower level of policy issue attitude congruence in the electorate in counties with different partisan distributions - that is, whether the probability of taking consistently conservative or liberal stances across a range of policy issues is context dependent. We may also be interested in approval ratings and feeling thermometer scores of more groups beyond presidential candidates. These possibilities should be considered in future research.

In spite of these caveats, from the results presented here we can confidently infer that political geography is one determinant of the degree to which the United States exhibits signs of partisan and ideological polarization. While the changing attitudes of our political elites surely plays an important role in this phenomenon, the changing political attributes of Americans' next-door neighbors seems to also be a major contributor.

${ }^{1}$ A case can be made that the use of a purely cross-sectional study may not be sufficient to make a persuasive case for the argument presented here. For that reason, these models were recreated using data from the 2008 presidential elections and more recent census data. These models can be found in the Appendix. The results of these models are substantively identical to the models generated using 2004 data.

\section{APPENDIX}

The preceding analysis was a purely cross sectional study relying on the 2004 National Annenberg Election Study (NAES). As a result, one may plausibly worry that the results presented were due to unusual circumstances of that election year, and a study of subsequent elections would yield differ ent results. For this reason, all models were recreated using data from the 2008 NAES and contextual data from that year (with the exception of the county religious data, for which I had no choice but to rely again on 2000 county data). The models for the different years were highly congruent, and in some cases the substantive and statistical significance of the key independent variable was even higher. 
Table A1. Multilevel Logit Model for Probability Respondents Were "Strong" Partisans

\begin{tabular}{|c|c|c|c|c|c|c|c|c|}
\hline & $\begin{array}{c}\text { Model 1 } \\
\text { Republicans }\end{array}$ & S.E. & $\begin{array}{l}\text { Odds } \\
\text { Ratio }\end{array}$ & S.E. & $\begin{array}{c}\text { Model } 2 \\
\text { Democrats }\end{array}$ & S.E. & $\begin{array}{l}\text { Odds } \\
\text { Odds }\end{array}$ & S.E. \\
\hline \multicolumn{9}{|l|}{ FIXED EFFECTS } \\
\hline \multicolumn{9}{|l|}{ Individual } \\
\hline Constant & -0.82 & $(0.14)^{* *}$ & & & 0.32 & $(0.15)^{*}$ & & \\
\hline Married & 0.08 & $(0.04)^{*}$ & 1.08 & $(0.04)$ & -0.10 & $(0.04)^{* *}$ & 0.90 & $(0.03)$ \\
\hline $\mathrm{BA}$ & 0.06 & $(0.03)$ & 1.06 & $(0.03)$ & 0.04 & $(0.04)$ & 1.04 & $(0.04)$ \\
\hline Female & 0.05 & $(0.03)$ & 1.05 & $(0.03)$ & 0.26 & $(0.03)^{* *}$ & 1.29 & $(0.04)$ \\
\hline Black & 0.08 & $(0.12)$ & 1.08 & $(0.13)$ & 0.91 & $(0.06)^{* *}$ & 2.48 & $(0.14)$ \\
\hline Hispanic & -0.25 & $(0.08)^{* *}$ & 0.78 & $(0.06)$ & -0.11 & $(0.06)$ & 0.89 & $(0.06)$ \\
\hline \multicolumn{9}{|l|}{ Frequently Attend } \\
\hline Religious Services & 0.35 & $(0.03)^{* *}$ & 1.42 & $(0.04)$ & -0.01 & $(0.04)$ & 0.99 & $(0.04)$ \\
\hline Age $30-44$ & 0.10 & $(0.06)$ & 1.10 & $(0.07)$ & 0.32 & $(0.07)^{* *}$ & 1.38 & $(0.09)$ \\
\hline Age 45-59 & 0.32 & $(0.06)^{* *}$ & 1.38 & $(0.08)$ & 0.57 & $(0.06)^{* *}$ & 1.76 & $(0.11)$ \\
\hline Age $60+$ & 0.56 & $(0.06)^{* *}$ & 1.75 & $(0.11)$ & 0.77 & $(0.07)^{* *}$ & 2.16 & $(0.14)$ \\
\hline Income Quartile 2 & 0.13 & $(0.04)^{* *}$ & 1.14 & $(0.05)$ & 0.08 & $(0.04)$ & 1.08 & $(0.05)$ \\
\hline Income Quartile 3 & 0.15 & $(0.05)^{* *}$ & 1.17 & $(0.06)$ & 0.14 & $(0.05)^{* *}$ & 1.15 & $(0.06)$ \\
\hline Income Quartile 4 & 0.28 & $(0.06)^{* *}$ & 1.32 & $(0.08)$ & 0.32 & $(0.07) * *$ & 1.38 & $(0.10)$ \\
\hline Income Unknown & 0.19 & $(0.05)^{* *}$ & 1.21 & $(0.07)$ & 0.04 & $(0.06)$ & 1.04 & $(0.06)$ \\
\hline \multicolumn{9}{|l|}{ Community } \\
\hline \% McCain 2008 & 0.01 & $(0.00)^{* *}$ & 1.01 & $(0.00)$ & -0.01 & $(0.00)^{* *}$ & 0.99 & $(0.00)$ \\
\hline$\%$ Black & 0.01 & $(0.00)^{* *}$ & 1.01 & $(0.00)$ & -0.01 & $(0.00)^{* *}$ & 0.99 & $(0.00)$ \\
\hline$\%$ Hispanic & 0.00 & $(0.00)$ & 1.00 & $(0.00)$ & 0.00 & $(0.00)^{* *}$ & 1.00 & $(0.00)$ \\
\hline Urban & -0.05 & $(0.05)$ & 0.96 & $(0.05)$ & 0.23 & $(0.06)^{* *}$ & 1.25 & $(0.07)$ \\
\hline Suburban & -0.01 & $(0.04)$ & 0.99 & $(0.04)$ & 0.10 & $(0.05)^{*}$ & 1.10 & $(0.05)$ \\
\hline Unempoyment Rate & 0.00 & $(0.01)$ & 1.00 & $(0.01)$ & 0.00 & $(0.01)$ & 1.02 & $(0.01)$ \\
\hline$\%$ Evang. Christian & 0.00 & $(0.00)$ & 1.00 & $(0.00)$ & 0.01 & $(0.00)^{* *}$ & 1.01 & $(0.00)$ \\
\hline \multicolumn{9}{|l|}{ State } \\
\hline South & 0.03 & $(0.06)$ & 1.03 & $(0.06)$ & 0.12 & $(0.07)$ & 1.13 & $(0.08)$ \\
\hline \multicolumn{9}{|l|}{ RANDOM EFFECTS } \\
\hline \multicolumn{9}{|l|}{ County-Level } \\
\hline \multicolumn{9}{|l|}{ Constant } \\
\hline$\sqrt{\psi}$ & 0.07 & $(0.06)$ & & & 0.13 & $(0.04)$ & & \\
\hline \multicolumn{9}{|l|}{ State-Level } \\
\hline \multicolumn{9}{|l|}{ Constant } \\
\hline$V_{\psi}$ & 0.09 & $(0.02)$ & & & 0.10 & $(0.02)$ & & \\
\hline \multicolumn{9}{|l|}{ GROUPS } \\
\hline \multicolumn{9}{|l|}{ Level-1 Observations } \\
\hline \multicolumn{9}{|l|}{$\begin{array}{l}\text { (Individual) } \\
\text { Level-2 Observations }\end{array}$} \\
\hline \multirow{2}{*}{\multicolumn{6}{|c|}{ (County) }} & 02 & & \\
\hline & \multicolumn{8}{|c|}{ Level-3 Observations } \\
\hline (State) & & 47 & & & & 47 & & \\
\hline
\end{tabular}


Table A2. Multilevel Logit Model for Probability Republican Respondents Described Themselves as "Very Conservative" and Democratic Respondents Described Themselves as "Very Liberal" (2008 Data)

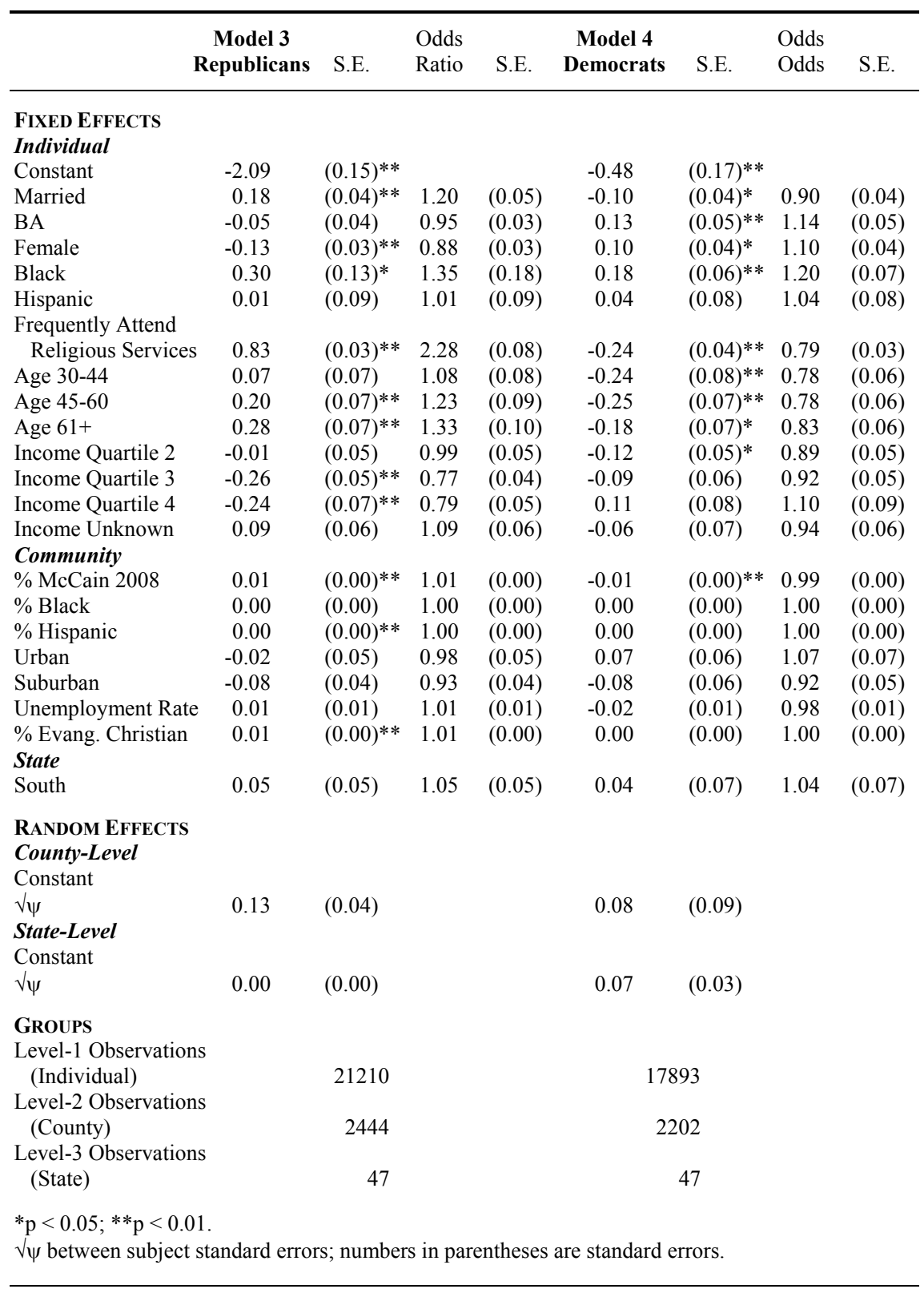


Table A3. Multilevel Linear Model for Difference in McCain-Obama Favorability Scores

\begin{tabular}{|c|c|c|c|c|c|c|}
\hline & $\begin{array}{c}\text { Model } 5 \\
\text { Republicans }\end{array}$ & S.E. & $\begin{array}{l}2 \text { Std. } \\
\text { Dev. } \Delta\end{array}$ & $\begin{array}{c}\text { Model } 6 \\
\text { Democrats }\end{array}$ & S.E. & $\begin{array}{l}2 \text { Std. } \\
\text { Dev. } \Delta\end{array}$ \\
\hline \multicolumn{7}{|l|}{ FIXED EFFECTS } \\
\hline \multicolumn{7}{|l|}{ Individual } \\
\hline Constant & 1.95 & $(0.19)^{* *}$ & & 4.26 & $(0.21)^{* *}$ & \\
\hline Married & 0.07 & $(0.05)$ & & 0.01 & $(0.05)$ & \\
\hline BA & -0.13 & $(0.04)^{* *}$ & & -0.02 & $(0.05)$ & \\
\hline Female & 0.15 & $(0.04)^{* *}$ & & 0.34 & $(0.05)^{* *}$ & \\
\hline Black & -0.55 & $(0.17)^{* *}$ & & 1.73 & $(0.07)^{* *}$ & \\
\hline Hispanic & -0.05 & $(0.11)$ & & -0.17 & $(0.09)$ & \\
\hline \multicolumn{7}{|l|}{ Frequently Attend } \\
\hline Religious Services & 0.25 & $(0.04)^{* *}$ & & -0.15 & $(0.05)^{* *}$ & \\
\hline Age $30-44$ & -0.05 & $(0.09)$ & & -0.30 & $(0.09)^{* *}$ & \\
\hline Age $45-60$ & 0.13 & $(0.09)$ & & -0.06 & $(0.09)$ & \\
\hline Age $61+$ & 0.66 & $(0.09)^{* *}$ & & 0.09 & $(0.09)$ & \\
\hline Income Quartile 2 & 0.35 & $(0.06)^{* *}$ & & 0.29 & $(0.06)^{* *}$ & \\
\hline Income Quartile 3 & 0.21 & $(0.07)^{* *}$ & & 0.20 & $(0.07)^{* *}$ & \\
\hline Income Quartile 4 & 0.38 & $(0.08)^{* *}$ & & 0.21 & $(0.09)^{*}$ & \\
\hline Income Unknown & 0.50 & $(0.08)^{* *}$ & & 0.39 & $(0.08)^{* *}$ & \\
\hline \multicolumn{7}{|l|}{ Community } \\
\hline$\%$ Bush 2004 & 0.01 & $(0.00)^{* *}$ & 0.32 & -0.01 & $(0.00)^{* *}$ & -0.39 \\
\hline$\%$ Black & 0.01 & $(0.00)^{*}$ & 0.17 & -0.01 & $(0.00)^{*}$ & -0.17 \\
\hline$\%$ Hispanic & 0.00 & $(0.00)^{* *}$ & 0.17 & 0.00 & $(0.00)$ & \\
\hline Urban & -0.17 & $(0.07)^{*}$ & & 0.13 & $(0.08)$ & \\
\hline Suburban & -0.07 & $(0.06)$ & & -0.03 & $(0.07)$ & \\
\hline Unempl. Rate, 2004 & 0.02 & $(0.02)$ & & -0.01 & $(0.02)$ & \\
\hline$\%$ Evang. Christian & 0.01 & $(0.00)^{*}$ & 0.16 & 0.00 & $(0.00)$ & \\
\hline \multicolumn{7}{|l|}{ State } \\
\hline South & 0.27 & $(0.08)^{* *}$ & & -0.01 & $(0.10)$ & \\
\hline \multicolumn{7}{|l|}{ RANDOM EFFECTS } \\
\hline \multicolumn{7}{|l|}{ County-Level } \\
\hline \multicolumn{7}{|l|}{ Constant } \\
\hline \multicolumn{7}{|l|}{ State-Level } \\
\hline $\begin{array}{l}\text { Constant } \\
\sqrt{\psi}_{\psi}\end{array}$ & 0.12 & $(0.04)$ & & 0.15 & $(0.07)$ & \\
\hline \multicolumn{7}{|l|}{ GROUPS } \\
\hline \multicolumn{7}{|l|}{ Level-1 Observations } \\
\hline \multicolumn{7}{|l|}{ Level-2 Observations } \\
\hline \multicolumn{7}{|l|}{ Level-3 Observations } \\
\hline
\end{tabular}




\section{REFERENCES}

Abramowitz, Alan I., and Kyle L. Saunders. 1998. Ideological Realignment in the U.S. Electorate. Journal of Politics 60:634-652.

Abramowitz, Alan I., and Kyle L. Saunders. 2002. Ideological Realignment and U.S. Congressional Elections. Pp. 203-213 in Understanding Public Opinion, 2nd ed., eds. Barbara Norrander and Clyde Wilcox. Washington, DC: CQ Press.

Abramowitz, Alan I., Brad Alexander, and Matthew Gunning. 2006. Don't Blame Redistricting for Uncompetitive Elections. PS: Political Science and Politics 39:8790 .

Abramowitz, Alan I., and Kyle L. Saunders. 2008. Is Polarization a Myth? Journal of Politics 70:542-555.

Abrams, Samuel J., and Morris P. Fiorina. 2012. 'The Big Sort' that Wasn't: A Skeptical Reexamination. PS: Political Science and Politics 45:203-210.

Allport, Gordon W. 1954. The Nature of Prejudice. New York: Doubleday.

Bafumi, Joseph, and Robert Shapiro. 2009. A New Partisan Voter. Journal of Politics 71(1):1-24.

Berelson, Bernard R., Paul F. Lazarsfeld, and William N. McPhee. 1954. Voting: A Study of Opinion Formation in a Presidential Campaign. Chicago: University of Chicago Press.

Bishop, Bill, and Robert G. Cushing. 2008. The Big Sort: Why the Clustering of LikeMinded America is Tearing Us Apart. New York: Mariner Books.

Books, John, and Charles Prysby. 1988. Studying Contextual Effects on Political Behavior: A Research Inventory and Agenda. American Politics Research 16:211238.

Brewer, Mark D., and Jeffrey M. Stonecash. 2007. Split: Class and Cultural Divides in American Politics. Washington, DC: CQ Press.

Brown, Thad. 1988. Migration and Politics. Chapel Hill: University of North Carolina Press.

Chinni, Dante, and James Gimpel. 2010. Our Patchwork Nation: The Surprising Truth about the 'Real' America. New York: Gotham Books.

Converse, Philip. 1964. The Nature of Belief Systems in Mass Publics. In Ideology and Discontent, ed. David Apter. New York: The Free Press.

DiMaggio, Paul, John Evans, and Bethany Bryson. 1996. Have Americans' Social Attitudes Become More Polarized? American Journal of Sociology 102:690-755.

Dodsen, Kyle. 2010. The Return of the American Voter? Party Polarization and Voting Behavior, 1988 to 2004. Sociological Perspectives 53(3):443-449.

Evans, John H. 1997. Worldviews or Social Groups as the Source of Moral Attitudes: Implications for the Culture Wars Thesis. Sociological Forum 12:371-404.

Evans, John H. 2002. Polarization in Abortion Attitudes in the U.S. Religious Traditions 1972-1998. Sociological Forum 17:397-422.

Evans, John H. 2003. Have Americans' Attitudes Become More Polarized? An Update. Social Science Quarterly 84:71-90.

Finifter, Ada W. 1974. The Friendship Group as a Protective Environment for Political Deviants. American Political Science Review 68:607-625.

Fiorina, Morris, Samuel J. Abrams, and Jeremy C. Pope. Culture War? The Myth of a Polarized America. New York: Pearson Longman.

Fischer, Claude S., and Greggor Mattson. 2009. Is America Fragmenting? Annual Review of Sociology 35:435-455. 
Gelman, Andrew, David Park, Boris Shor, Joseph Bafumi, and Jeronimo Cortina. 2008. Red State, Blue State, Rich State, Poor State: Why Americans Vote the Way They Do. Princeton, NJ: Princeton University Press.

Gershkoff, Amy R. 2009. The Marriage Gap. In Beyond Red State, Blue State: Electoral Gap in the Twenty-First Century American Electorate, eds. Laura Olson and John C. Green. Upper Saddle River, NJ: Pearson Prentice Hall.

Gimpel, James G., Frances E. Lee, and Joshua Kaminski. 2006. The Political Geography of Campaign Contributions in American Politics. Journal of Politics. 68:3:626-639.

Gimpel, James G., and Jason E. Schuknecht. 2003. Patchwork Nation: Sectionalism and Political Change in American Politics. Ann Arbor: University of Michigan Press.

Gimpel, James G., and Dante Chinni. 2010. Our Patchwork Nation: The Surprising Truth about the "Real" America. New York: Penguin Books.

Hetherington, Marc J. 2001. Resurgent Mass Partisanship: The Role of Elite Polarization. American Journal of Political Science 95:619-31.

Huckfeldt, Robert. 1983. Social Contexts, Social Networks, and Urban Neighborhoods: Environmental Constraints on Friendship Choice. American Journal of Sociology 89:651-669.

Huckfeldt, Robert, J. Mendez, and T. Osborne. 2004. Disagreement, Ambivalence, and Engagement: The Political Consequences of Heterogeneous Networks. Political Psychology 25:65-95.

Hunter, James D. 1991. Culture Wars: The Struggle to Define America. New York: Basic Books.

Jennings, M. Kent, and Gregory B. Markus. 1984. Partisan Orientations over the Long Haul: Results from the Three-Wave Political Socialization Panel Study. American Political Science Review 78:1000-1018.

Jones, Dale E., Sherri Doty, Clifford Grammich, James E. Horsch, Richard Houseal, Mac Lynn, John P. Marcum, Kenneth M. Sanchagrin, Richard H. Taylor. 2002. Religious Congregations and Membership in the United States, 2000. Nashville, TN: Glenmary Research Center.

Keith, Bruce E., David B. Magleby, Candice J. Nelson, Elizabeth Orr, Mark C. Westlye, and Raymond E, Wolfinger. 1992. The Myth of the Independent Voter. Berkeley: University of California Press.

Key, V.O. 1949. Southern Politics in State and Nation. Knoxville: University of Tennessee Press.

Klinkner, Philip A. 2004. Red and Blue Scare: The Continuing Diversity of the American Electoral Landscape. The Forum Vol. 2, Article 2

Layman, Geoffrey C., Thomas M. Carsey, and Juliana Mensasce Horowitz. 2006. Party Polarization in American Politics: Characteristics, Causes, and Consequences. Annual Review of Political Science 9:83-110.

Levendusky, Matthew. 2009. The Partisan Sort: How Liberals Became Democrats and Conservatives Became Republicans. Chicago: University of Chicago Press.

MacKuen, Michael, and Courtney Brown. 1987. Political Context and Attitude Change. American Political Science Review 81:471-490.

McCarty, Nolan, Keith Poole, and Howard Rosenthal. 2006. Polarized America: The Dance of Ideology and Unequal Riches. Cambridge, MA: MIT Press.

McClerking, Harwood K. 2009. Racial and Ethnic Gaps. In Beyond Red State, Blue State: Electoral Gaps in the Twenty-First Century American Electorate, eds. Laura Olson and John C. Green. Upper Saddle River, NJ: Pearson Prentice Hall. 
McClurg, Scott D. 2006. Political Disagreement in Context: The Conditional Effect of Neighborhood Context, Disagreement and Political Talk on Electoral Participation. Political Behavior 28(4):349-366.

McPherson, Miller, Lynn Smith-Lovin, and James M. Cook. 2001. Birds of a Feather: Homophily in Social Networks. Annual Review of Sociology 27:415-444.

McVeigh, Rory, and Juliana M. Sobolewski. 2007. Red Counties, Blue Counties, and Occupation Segregation by Race and Sex. American Journal of Sociology 113(2): 446-506.

Miller, Warren E. 1956. One-Party Politics and the Voter. American Political Science Review 50(3):707-725.

Mollenhorst, Gerald, Beate Völker, and Henk Flap. 2008. Social Contexts and Personal Relationships: The Effect of Meeting Opportunities on Similarity for Relationships of Different Strength. Social Networks 30:60-68.

Mutz, Diana C. 2002a. The Consequences of Cross-Cutting Networks for Political Participation. American Journal of Political Science 46:838-855.

Mutz, Diana C. 2002b. Cross-cutting Social Networks: Testing Democratic Theory in Practice. American Political Science Review 96:111-126.

Poole, Keith T., and Howard Rosenthal. 1997. Congress: A Political-Economic History of Roll Call Voting. New York: Oxford University Press.

Putnam, Robert D. 1966. Political Attitudes and the Local Community. American Political Science Review 60:640-654.

Rhode, David W. 1991. Parties and Leaders in the Post-Reform House. Chicago: University of Chicago Press.

Steenbergen, Marco R., and Bradford S. Jones. 2002. Modeling Multilevel Data Structures. American Journal of Political Science 46:218-237.

Stoker, Laura, and M. Kent Jennings. 2008. Of Time and Development of Partisan Polarization. American Journal of Political Science 52:619-635.

Stonecash, Jeffrey M., Mark D. Brewer, and Mack Mariani. 2003. Diverging Parties: Social Change, Realignment, and Party Polarization. Boulder, CO: Westview.

Walton, Hanes, and Robert Smith. 2006. American Politics and the African American Quest for Universal Freedom. New York: Pearson Longman.

Woodard, J. David. 2006. The New Southern Politics. Boulder, CO: Lynne-Rienner.

Zaller, John. 1990. Political Awareness, Elite Opinion Leadership, and Mass Survey Response. Social Cognition 8:125-153. 